\title{
The Impact of Microfinance on Female Empowerment in Egypt
}

\author{
Dr. Hala El Hadidi \\ Lecturer in Economics \\ Faculty of Business Administration \\ Economics and Political Science \\ British University in Egypt
}

\begin{abstract}
Microfinance has become a major instrument for the alleviation of poverty in many developing economies and a tool for female empowerment. In Egypt, it has been used to fight poverty and the country is one of the largest microfinance markets in the Arab region. At year - end 2012, the Egyptian market consisted of some 1.3 million active clients and a gross loan portfolio of US\$324 million. Between 2005 and 2010, the number of microfinance women borrowers in Egypt increased by 47\% annually from 550,000 to 1.3 million, placing Egypt first among Arab countries in terms of the number of microfinance women clients. However, the impact of microfinance on women in Egypt is still questionable and many researchers are sceptical about the results of these programmes on women's economic, political, social, and psychological improvement.

This paper presents, therefore, the historical context in which the microfinance programmes have evolved in Egypt and explores the different affects they have on Egyptian women, based on a questionnaire survey of a convenience sample of 300 women currently receiving microfinance credit. The paper identifies the changes in the lives of these women and the results indicate that all microfinance variables (Loan value, Average income, and Project value) are significantly correlated with the different aspects of empowerment. Notably psychological empowerment has the highest correlation with microfinance variables, followed by social empowerment, economic empowerment, and finally political empowerment. The article proposes that changes are needed in how microfinance is delivered in Egypt in order to alleviate poverty and empower Egyptian women.
\end{abstract}

\section{Introduction}

\section{Theoretical Background}

Microfinance is a financial service targeted at the unemployed and low income groups. It aims to help them become self-sufficient and is particularly prominent in developing economies where it has come to play a major role in gender and development strategies because of its direct relationship to both poverty alleviation and female empowerment. The theory holds that by giving women access to working capital and training, microfinance helps mobilise their productive capacity to alleviate poverty and maximise eco-

* تم تسلم البحث في سبتمبر 2015، وقبل للنشر في نوفمبر 2015. 
nomic output. In this case, women's entitlement to financial services, development aid and equal rights rests primarily on their potential contribution to society rather than on their intrinsic rights as human beings and members of that society (Agnes, 2012).

It is generally accepted that women are disproportionately represented among the world's poorest people. In its 2010 Human Development Report, the United Nations Development Programme (UNDP) reported that 70 percent of the 1.3 billion people living on less than $\$ 1$ per day are women (UNDP, 2010). According to the World Bank's gender statistics database (2015), women have a higher unemployment rate than men in virtually every country. In general, women also make up the majority of the lower paid, unorganised informal sector of most economies (Deshpanda, 2012; Rahman, 2015), and although development agencies have noted an apparent trend towards the "feminisation of poverty," measuring the extent to which this is occurring presents many challenges. Because most methods of measuring poverty assess the level of poverty of the household as a whole, it is likely that poverty experienced by women as a result of discrimination against them within their households is under reported. By providing women with access to financing for income-generating activities, therefore, microfinance institutions can significantly reduce the vulnerability of women to poverty and it may be contested that a reduction in women's vulnerability can sometimes also translate into empowerment if greater financial security allows them to become more assertive in household and community affairs (Chalfin, 2010).

Women spend more of their income on their households, so when women are helped to increase their incomes, the welfare of the whole family is improved. In its report on its survey findings the Special Unit on Microfinance of the USAID explains, "Women's success benefits more than one person. Several institutions confirmed the well-documented fact that women are more likely than men to spend their profits on household and family needs. Assisting women therefore generates a multi effect that enlarges the impact of the institutions' activities." (2013p.). The Women's Entrepreneurship Development Trust Fund (WEDTF), also reports that "women's increased income benefits their children, particularly in education, diet, health care, and clothing." According to a WEDTF report, 55 percent of women's increased income is used to purchase household items, 18 percent goes for school, and 15 percent is spent on clothing (Whitehead 2011, p 530)

Empowerment is defined as "enabling each person to reach his or her God-given potential." (Saith, et al 2013, p 466). The terms self-reliance and self-respect are also used to define it (Saith, et al 2013). According to Salib, (2014, p. 67) "Empowerment is gaining the ability to generate choices and exercise bargaining power", also "developing a sense of self-worth, a belief in one's ability to secure desired changes, and the right to control one's life". Empowerment is an implicit, if not explicit, goal of a great number of microfinance institutions around the world. Empowerment is about change, choice, and power. It is a process of change by which individuals or groups with little or no power gain the power and ability to make choices that affect their lives. The structures of power-who has it, its sources, and how it is exercised - directly affect the choices that women are able to make in their lives (Agnes, 2012). Microfinance programmes can have a tremendous impact on the empowerment process if their products and services take these structures into account. In order for a woman to be empowered, she needs access to the material, human, and social resources necessary to make strategic choices in her life (Amolat, 2010). Not only have women been historically disadvantaged in access to material resources like credit, property and money, but they have also been excluded from social resources like education. Access to resources alone does not automatically translate 
into empowerment or equality, however, because women must also have the ability to use the resources to meet their goals (Bayulgen, et al. 2012). In order for resources to empower women, they must be able to use them for a purpose that they choose (Razavi, 2014; Quisumbing et al, 2014),

According to Oxaal, et.al. (2013, p.540) "Empowerment of women and gender equality are prerequisites for achieving political, social, economic, cultural, and environmental security among all people". The basic theory is that microfinance empowers women by putting capital in their hands and allowing them to earn an independent income and contribute financially to their households and communities (Engle, 2012). This economic empowerment is expected to generate increased self-esteem, respect, and other forms of empowerment for women. Involvement in successful income-generating activities should translate into greater control and empowerment. However, this may not always hold true and complacency in these assumptions can lead Microfinance institutions (MFIs) to overlook both opportunities to empower women more profoundly and failures in empowerment (Anderson, et al. 2013). The ability of a woman to transform her life through access to financial services depends on many factors — some of them linked to her individual situation and abilities, and others dependent upon her environment and the status of women. Control of capital is only one dimension of the complex and ever-changing process by which the cycles of poverty and powerlessness replicate themselves (Ashe, et al. 2010). Women also face disadvantages in accessing information, social networks, and the other resources they need to succeed in business and life. Only by evaluating the needs of women will Microfinance institutions (MFIs) be able to maximise empowerment potential (Sen, 2012).

The economic and social effects of micro-financing have been extensively studied in a wide range of policy analyses and scholarly works (Chalfin, 2010; Drolet, 2010 a; Dunford, 2013) and micro-financing has been shown to be correlated positively with economic development by reducing poverty, improving welfare and allowing poor people to protect, diversify, and increase their sources of income and assets. By creating jobs through self-employment and new businesses, micro-financing promotes a more productive use of capital and has a direct and positive impact on local economies. Micro-financing is also shown to impact social development and the quality of life by promoting environmental sustainability and improving family expenditures on education, thereby contributing to improving the human capacity of poor families, and reducing family expenditures on health care through improvements in housing, water, and sanitation and ensuring food security. Through income creation opportunities, microfinance can help fight social exclusion by integrating traditionally marginalised groups into the economic system (Druschel, 2013).

In order to demonstrate how microfinance may possibly enhance political empowerment, it is necessary to understand what it is and why it is so important in developing countries. Conventional financial systems around the world typically exclude the poor. In developing countries, microfinance has demonstrated its potential for delivering a full range of commercial financial services to micro-entrepreneurs and poor families that are conventionally considered "unbankable" due to high transaction costs, perceived risks, low margins, and the lack of traditional collateral. By providing financial services to the economically active poor, MFIs expand the frontier of the financial sector, drawing previously excluded groups into active participation in the financial system, increasing the economy's financial depth and generating more broad-based economic growth (MkNelly, et al. 2015). Access to flexible, convenient and affordable financial services empowers and equips the poor to make their own choices and build their way out of poverty in a sustained 
and self-determined way. Thus micro-financing is a particularly inclusive, participatory and non-paternalistic development tool. It offers "hope to many poor people of improving their own situations through their own efforts" (MkNelly, et al. 2015, p 435) and as such is different from other anti-poverty policies, such as international aid and debt forgiveness which are essentially top-down rather than bottom-up approaches.

\section{Empirical Findings}

There are a number of constraints for using microfinance as a strategy to reduce poverty among poor women and as a tool for the economic empowerment of women in Egypt. These relate to the nature of microfinance services and the way they are delivered and used, and to the limitations of microfinance in terms of poverty reduction, and the empowerment of women. Among these constraints are access to financial services by women, lack of control over microfinance loans by women users, shortcomings in definition, measurement and analysis of poverty among women and shortcomings in the measurement of women's empowerment (Nader, 2012).

Research on microfinance and the empowerment of women is very ambivalent though there is a huge body of literature arguing that microfinance improves the economic status of women and empowers them. Ashe (2010) suggests that by providing women with a source of income of their own, microfinance programmes reduce their economic dependency on their partners and increase their "domestic prestige." He further argues that the exposure to new ideas and values, such as those promoted by the lending organisation, allows women to be more assertive of their rights.

These findings are supported by the many stories printed and posted on the Internet by providers of microfinance who list self-respect; dignity; self-dependence; courage; human spirit; and triumph over the cruelties of poverty as results of microfinance. Paradoxically, Chalfin (2010) argues that in microfinance institutions, women's interests are subsumed and subordinated to the aspirations of the NGOs and that the success of microfinance programmes is the result of activities of institutions that are considered oppressive of women. Writing about the experience in Egypt, Dunford (2013) notes that women who take credit are abused by their husbands who seek to seize this extra source of income. Such findings correspond with the research of Drushel et al (2013) on loan use by rural women in Bangladesh. They noted that a significant proportion of women's loans were controlled by male relatives, leading to exacerbating tensions within the household and to the undermining of the survival strategies of the household when men invest loans badly and women are forced to repay it.

In a study by Barsoum (2011), it was found that $43 \%$ of women compared with $57 \%$ of men noticed a positive change and empowerment as a result of participating in microfinance programmes. $25 \%$ of women clients and $23 \%$ of men clients noticed a positive effect on their businesses, while $10 \%$ of women but $30 \%$ of men noticed a negative effect on their domestic tasks. This suggests that the sense of empowerment in this domain is stronger for women than men (Barsoum 2011). 


\section{The Egyptian Context}

\section{The provision of Micro-Financial Services in Egypt}

Microfinance is not a new concept. Small micro-credit services have been provided since the $1700 \mathrm{~s}$ but in Egypt it was not until the 1950s that agricultural micro-lending was made available through the government-owned bank, Principal Bank for Development and Agriculture (PBDAC). Since then, numerous other initiatives have been introduced such as the Productive Families project (PF), which was initiated by the Ministry of Social Affairs in 1977 to provide microcredit to low-income families, conditional on having a government employee guarantor. In 1982, the United Nations Children's Fund (UNICEF) launched a programme for rural women with a focus on female-headed households. The programme was implemented by the Ministry of Social Affairs while the Ford Foundation funded the Association for Garbage Collectors in Cairo in 1983 to provide credit and employment-related training (Barsoum, 2011). The project now operates under the auspices of the Ministry of Rural Development.

The field of microfinance in Egypt dramatically changed in the late 1980s. In 1988 an initiative by the United States Agency for International Development (USAID) in Egypt geared such changes (USAID, 2013). USAID funds were earmarked for the development of the small and micro-enterprise sector. The fund was directed toward seed capital, institutional development financing, training and technical assistance, and research (USAID 2013). USAID designed two models for the delivery of credit in Egypt: the foundation model and the bank model. The foundation model was to establish not-for-profit foundations to serve as intermediaries between individual borrowers and the lending banks where seed funds were deposited as a guarantee of a credit line for these borrowers (USAID, 2013). Two foundations were first established: the Small Enterprise Development Foundation (Cairo Foundation, which provides credit in the Cairo governorate) and the Alexandria Small Business Association (ABA). The model was later replicated in five other governorates: Port Said (1995), Assuit (1996), Sharkyla (1997), Dakahleya (1998), and Kafr El-Sheikh (1999). The bank model was implemented by the National Bank for Development with staff in 13 of its branches dedicated to the provision of small and micro-enterprise lending and mobile units radiating out of each branch (USAID 2013).

While expanding the field significantly, the USAID contribution initiated a new stream in the microfinance field in Egypt that distinguished it from the earlier experience. It emphasised the business enhancement model vis-a-vis the earlier poverty alleviation model. Different methodologies and targeting mechanisms emerged. The new target group was small businesses in urban locations instead of the earlier emphasis on rural home-based activities. The clientele of the new initiative was largely male despite the donors' emphasis on a female presence. Loan sizes were relatively large. More emphasis was placed on programme self-sufficiency, sustainability, and even profitability (USAID, 2013) as opposed to the earlier reliance on donor funds. In their targeting schemes, programmes emphasised the economic potential of the borrower rather than their poverty. Extension officers were predominantly male and a strict bonus and salary system was implemented in order to tie the repayment rate of the borrowers to the income of the extension officer who chose them and was responsible for the collection of their loan installments. This wage system constituted a vital mechanism that ensured that only prospering businesses received credit and that volatile or low-income economic activities were filtered out. 
Established in 1991, the Social Fund for Development (SFD) is currently the largest donor programme in the field of small and micro-enterprise lending in Egypt. SFD functions as a governmental organisation that was initiated specifically to mitigate the negative impact of structural adjustment policies and acts as an intermediary between international donors and local constituencies. More than $70 \%$ of the budget of the Fund for Phase 2 dated (1997-2000) was allocated for the two main programmes providing credit at SFD: the Small Enterprise Development Organization (SEDO) and the Community Development Program (CDP) (Nader, 2012). These two programmes neatly follow the distinction already existing in the field between the economic survival model and the business enhancement model.

SEDO targets unemployed youth and new graduates with relatively larger loans (35,000 Egyptian pounds) following the business enhancement growth model. In 2000, more than LE 2.3 billion was committed to support small enterprises (USAID, 2013). Most of the credit recipients are males in urban areas. Credit is provided through governmental and commercial banks and is subsidised at a differentiated interest rate structure depending on the loan size, the borrower's type of business, duration of the loan, and whether the loan is for a start-up or an existing business. The emphasis of these programmes is on the informal sector and micro-entrepreneurs and the loan approval requirements of many of them include a work permit, economic activity licensing, social security registration, tax card, and commercial registry, which are documents unavailable among micro entrepreneurs working in the informal sector.

CDP, on the other hand, provides revolving funds to grassroots organisations for the provision of microcredit for poverty alleviation and economic survival. These organisations include local and international NGOs, CDAs, branches of the PBDAC, and offices of the government. Priority is given to organisations operating in the poorer communities in Upper Egypt, Delta, and squatter urban settlements in Cairo. Following the economic survival model, CDP considers credit an element of an integrated package including primary health care, literacy, community schools, female empowerment, population and family planning, and environment (USAID, 2013).

Intermediary organisations are required to consider these aspects in designing their lending programmes. Credit is provided on a group collateral basis at a low interest rate (7\%). In 1997, USAID renewed its support to the microfinance field in Egypt by starting a new agreement with the Credit Guarantee Corporation (CGC) to serve as an umbrella organisation that provides technical and financial services to different implementing entities, from NGOs and CDAs. CGC was established in 1990 with funding from USAID and nine Egyptian financial institutions as a not-for-profit corporation in order to "assist in the delivery of credit to small businesses that lack sufficient collateral to obtain loans from banks" (USAID 2013).

Although the SFD and USAID are the current major donors in the field of microfinance in Egypt, there is a plethora of programmes funded through other donors. Economic reform policies in the1990s rendered microfinance an embraced mechanism for poverty alleviation and employment generation. Virtually every donor with a poverty alleviation mandate in Egypt supported or continues to support microfinance programmes by providing seed capital, technical support, or research and information dissemination. The list includes, but is not limited to, the Canadian International Development Agency, UNICEF, the Ford Foundation, the National Council of Negro Women, the Egyptian-Swiss Development Fund, Save the Children, the German Agency for Technical Co-operation, the Netherlands Organization for International Development 
Co-operation, the United Nations Development Programme (UNDP), the Friedrich Ebert Foundation, the Italian Fund of Egypt, and more recently the European Commission's MEDA Programme (the Euro-Mediterranean Partnership) (Nader, 2012).

\section{The Impact of Micro-Finance in Egypt}

The long list of donors, however, does not mean that microfinance has become widely available in Egypt. According to the United Nations Capital Development Fund (UNCDF), 95\% of the potential demand for microfinance in Egypt is not being met (Barsoum, 2011).

Since the beginning of the 1990s microfinance programmes specifically targeted at women have been one of the principal strategies for poverty alleviation by the international community of donors. The aim is to provide financial services to low income households to alleviate poverty and to empower women with operational and financial self-sufficiency based on access to international financial markets (Barsoum, 2011).

The number of female microfinance borrowers in Egypt increased by $47 \%$ annually from 550,000 to 1.3 million between 2005-2010, placing Egypt first among Arab countries in terms of the number of female microfinance clients. In 2008, the Egyptian market consisted of some 1.3 million active women clients and a gross loan portfolio of US\$324 million (Drolet, 2010 b). Since then (2008), 65\% of the clients are women and programmes are designed to address the role of women in promoting poverty reduction through local development in Egypt (Nader, 2012).

Within the microfinance framework, women are afforded the opportunity to start small businesses in and around their homes so they are not compelled to leave their children at home alone. Examples of such businesses include selling vegetables, other groceries, self-made clothing items or accessories. Women are thus able to provide sustenance, education and medical care for their children, providing them with the opportunity for improved social and professional standing (Barsoum 2011).

Despite these various interventions 44\% of Egyptians lived on less than $\$ 2$ a day in 2014, which represents nearly 30 million persons, and the World Bank claims that although Egypt is improving with respect to certain social and economic indicators, progress still needs to be made in many areas (World Bank, 2015). Therefore, the development of microfinance can be seen as a tool to fight against poverty, especially in a country where micro and small enterprises play a substantial role in economic life, representing $39.5 \%$ of the total Egyptian workforce (Nader, 2012).

As mentioned, many microfinance programmes are directly targeting women and according to Nader (2012) the average female microfinance client in Egypt is a 40 year old, married woman, with no formal education and unable to read. She works as a trader and does not have a second income-generating activity. She has been running a home-based activity for the past 3 to 5 years (Nader, 2012).

The distribution of wealth by gender shows a significant difference between males and females. The proportion of relatively wealthier microfinance clients is higher among men than women in Egypt. Likewise the lack of formal education is mainly present in the female population of clients (32\% for women versus $9 \%$ for men). The proportion of women is much higher in certain sector activities. Women desire smaller 
loan amounts than men. The size of loans demanded by women is lower by $500 \%$ than loans demanded by men (Barsoum 2011).

\section{Aims and Methodology}

Against this theoretical and contextual background, the aim of the study is to investigate the impact of Microfinance on female empowerment in Egypt in an attempt to determine whether micro-finance does lead to the empowerment of Egyptian women as theory suggests. To achieve its objective, the study is based on a self-administered questionnaire survey of a convenience sample of 400 women accessing micro-finance credit from the programmes of the Principal Bank for Development and Agricultural Credit and the Social Fund for Development. Of these, 300 completed the survey with the help of a survey administrator, yielding a 75 per cent response rate.

The questionnaire, which was in Arabic, was intended to measure four aspects of female empowerment, namely economic, political, social and psychological empowerment. It was developed by the author based on the literature and comprises 35 different measures (see Table 1). Economic empowerment was measured using 10 items, Political empowerment 7 items, Social empowerment 8 items and Psychological empowerment 10 items. Participants were asked to evaluate each of these measures after receiving the microfinance credit by comparing their present situation with their lives prior to receiving the micro-finance, using a three-point scale; - improved (3), the same (2) and worse (1). Cronbach's Alpha for these subscales were.733,.795,.753 and the total was.895 respectively, suggesting an accepted level of reliability. In addition, personal profile data were collected for each participant (eg. Age, marital status, education etc.) together with details of the loan (eg. Loan value, interest rate etc.) data were collected from each participant.

As mentioned the participants were approached while managing their credit loans in two main governmental institutions, namely Principal Bank for Development \& Agricultural Credit (PBDAC) and Social Fund for Development (SFD). Each participant was asked to participate in the study after explaining the main purpose of the project. Written consents were collected and 50 EGP were provided as compensation for participation.

\section{Results and Findings}

\section{Sample Profile.}

The results reveal that the age range of the participants was 22 to 62 , with an average age of 40 years old as reported by Nader (2012). 40 per cent of the respondents were married, $27.7 \%$ were divorced and $25 \%$ were widowed. 7.3 per cent had never been married. $29.7 \%$ of the sample were illiterate, $31 \%$ could read and write, $24.3 \%$ finished their primary education, $8 \%$ and $7 \%$ finished preparatory and secondary education respectively. 48.7 per cent of the women had worked previously while 51.3 per cent had had no prior employment.

For $71.7 \%$ of the women in the sample this was not their first time to obtain a loan. Just over one third (35.3 per cent) had received 1 or 2 loans, but some 10 per cent had received 10 or more. $63 \%$ claimed that the loan was their main source of income but $35.7 \%$ of the sampled women had other income sources. 
These included governmental job (0.3\%), private job (1\%), another project (4\%), pension (9\%), loans (11\%) and others $(9 \%)$, while $65 \%$ had no other sources of income.

The average loan value is $2760.17 \mathrm{EGP}(\$ 352.5)$ with a minimum of $250 \mathrm{EGP}(\$ 31.9)$ and a maximum of 5000 (\$638.5). The average interest rate is $17.565 \%$ per annum with a minimum of $10 \%$ and a maximum of $25 \%$ per annum.

As for the reasons for the loans, $77 \%$ were for business enlargement, $13 \%$ for financial needs and $10 \%$ to start a new project. $39 \%$ faced difficulties in servicing the loan resulting from loss (12.7\%), family needs (13.3\%), work instability (12.7\%) and crises (0.3\%).

\section{Female Empowerment}

Table 1 shows the four types of empowerment and the extent to which the loan impacted the lives of women in the sample.

\section{Table 1: The four types of empowerment}

\begin{tabular}{|c|c|c|}
\hline \multicolumn{2}{|c|}{ Economic impact } & \multirow{2}{*}{$\begin{array}{c}\text { Percent } \\
77.3 \%\end{array}$} \\
\hline 1. & Acquire more economic resources (money, loans) & \\
\hline 2. & Acquire loans for projects & $77.3 \%$ \\
\hline 3. & Marketing Products & $76.7 \%$ \\
\hline 4. & Work in Stable Environment & $75.3 \%$ \\
\hline 5. & Acquire Profit & $73.3 \%$ \\
\hline 6. & Ability to Support Family & $71 \%$ \\
\hline 7. & Acquire help in work & $68 \%$ \\
\hline 8. & Investing in other Projects & $67.7 \%$ \\
\hline 9. & Acquire help in work from family members & $65.7 \%$ \\
\hline 10. & Project Registration & $61.3 \%$ \\
\hline \multicolumn{3}{|c|}{ Political impact } \\
\hline 11. & Teaching of family members the importance of political participation & $68 \%$ \\
\hline 12. & Acquire political rights & $67.3 \%$ \\
\hline 13. & Feeling of empowerment in society & $66.7 \%$ \\
\hline 14. & Voting & $64.3 \%$ \\
\hline 15. & Political freedom & $62.3 \%$ \\
\hline 16. & Becoming a member of parliament & $62 \%$ \\
\hline 17. & Participation in women's rights institutions & $59.3 \%$ \\
\hline \multicolumn{3}{|c|}{ Social impact } \\
\hline 18. & Acquire better health services for family members & $78.7 \%$ \\
\hline 19. & The participation in directing the family life & $77.7 \%$ \\
\hline 20. & Social participation in the family life & $77.3 \%$ \\
\hline 21. & Acquire better education services for family members & $76.7 \%$ \\
\hline 22. & Radical Change in the life of the Family & $75.3 \%$ \\
\hline 23. & Acquire better housing for family members & $74.7 \%$ \\
\hline
\end{tabular}


Economic impact

24. The participation in managing the family

25. The ability to take decisions inside the family

\section{Psychological impact}

26. Self-Respect

27. Self Confidence

28. Ability to think Positively

29. The ability to control your own life

30. Ability to learn new things

31. Ability to make your own choice in life

32. Feeling of Self-Efficacy

33. The ability to make others depend on you

34. Yourself positive image

35. The ability to negotiate your own rights

It reveals that the greatest impact of micro-finance on Egyptian women was psychological, giving them greater self-confidence and self respect. This is important, particularly given the culture and the traditional role of women in Egyptian society. Notably, micro finance also impacted on their social lives giving them the opportunity to improve, in particular, the conditions of their families, while it also impacted, to a lesser extent, on their economic circumstances especially by permitting them to acquire further funding - hence the majority had had more than one loan. Political empowerment, however, remained somewhat limited, both in the community and the family. This is not surprising, perhaps, given the culture, the traditional role of women and the fact that the political system in Egypt is in transition.

To examine the relationships between microfinance variables and the different aspects of female empowerment, Pearson correlation coefficients were calculated as shown in Table 2.

\section{Table 2: Correlation matrix between microfinance variables and different aspect of women} empowerment

\begin{tabular}{lccc}
\hline & Loan Value & Average Income & Project value \\
\hline Economic empowerment & $.213^{* *}$ & $.153^{*}$ & $.168^{*}$ \\
\hline Political empowerment & $.141^{*}$ & $.195^{* *}$ & $.144^{*}$ \\
\hline Social empowerment & $.215^{* *}$ & $.161^{*}$ & $.199^{* *}$ \\
\hline Psychological empowerment & $.217^{* *}$ & $.224^{* *}$ & $.321^{* *}$ \\
\hline Empowerment (Total) & $.214^{* *}$ & $.142^{*}$ & $.219^{* *}$
\end{tabular}

significant at $\mathrm{p}<.05, * *$ significant at $\mathrm{p}<.01 *$

The results indicate that all microfinance variables (Loan value, Average income, and Project value) are significantly correlated with different aspects of empowerment but it is worth noting again that psychological empowerment has the highest correlations with microfinance variables, followed by social empowerment, economic empowerment, and finally political empowerment. 
To further explain the effect of microfinance variables (only project value due to multi-collinearity) on different aspects of female empowerment, simple regression analyses were fitted as shown in Table 3.

Table 3: Regression analysis to predict different types of empowerment using project value as a predictor

\begin{tabular}{lccccc}
\hline Dependent variable & $\mathbf{R}$ & R-square & F-value & B & t-value \\
\hline Economic empowerment & .168 & .035 & $5.87^{* *}$ & .049 & $2.47^{* *}$ \\
\hline Political empowerment & .144 & .021 & $6.29^{* *}$ & .055 & $2.51^{* *}$ \\
\hline Social empowerment & .199 & .039 & $12.23^{* *}$ & .073 & $3.49^{* *}$ \\
\hline Psychological empowerment & .321 & .102 & $33.95^{* *}$ & .094 & $5.83^{* *}$ \\
\hline Empowerment (Total) & .219 & .048 & $15.05^{* *}$ & .082 & $3.88^{* *}$ \\
\hline
\end{tabular}

** significant at $\mathrm{p}<.01$

The results reveal that project value can explain $10.2 \%$ of the total variance of psychological empowerment, $3.9 \%$ of the total variance of social empowerment, $3.5 \%$ of the total variance of economic empowerment, and $2.1 \%$ of the total variance of political empowerment. Hence, the larger the project the greater the impact, particularly for psychological empowerment.

\section{Conclusion}

The aim of this study was to examine the impact of micro-finance on the empowerment of women in Egypt. It is based on a questionnaire survey of some 300 women using two major micro-finance programmes and reveals that access to micro finance, despite any difficulties the recipients may experience, does impact positively on female empowerment. Most significantly it empowers women psychologically impacting on their self-confidence and self-esteem, but it also empowers them socially, and, to a lesser extent, economically and politically. Economic empowerment appears relatively limited, however, in comparison, which probably results from the small size of the loans (average 2760 EGP) and/or the expected rates of interest/repayment ( $17.56 \%$ per annum). Noticeably some $39 \%$ of the sample were experiencing difficulties servicing the loans and over one-third of the sample had other sources of income.

Hence, it would seem that currently micro-finance has only a limited impact on the economic empowerment of Egyptian women and the eradication of poverty in the country. Accordingly, it would seem there is a need, as Anderson et al (2013) have recognized, for microfinance institutions to explore further opportunities to empower women and the Egyptian Government might need to consider ways in which this situation may be improved and the economic multiplier resulting from micro finance projects might be increased. While it is possible that this is a temporary problem, resulting from the prevalent political and economic instability in the country, it is more likely to be the result of the mechanisms themselves and the nature of the projects embarked upon by the recipients. More information is needed on this and on the scalability of the projects, but, as the literature suggests, often women's projects in particular are highly localised with only limited opportunities for market expansion. This might explain why the loans to Egyptian women are considerably lower than those to their male counterparts. Further, in those projects that have market potential beyond their immediate catchment, often the recipients lack the awareness and know how to capitalise on the opportunities. It may be that mentoring and training are needed to help grow and 
develop such enterprises but more needs to be known about the nature of the projects and their scope and potential. Additionally, it may require concentration of resources in order to develop the critical mass necessary to bring about the required changes and improvement. This would suggest a need for more detailed in-depth case analyses and, possibly, a longitudinal study to monitor performance over time, together with an evaluation of the needs of women as Sen (2012) has suggested.

The study also indicates that micro-finance projects have relatively little impact on female political empowerment in Egypt, both nationally and locally. Given the culture, the traditional role of women in society and the fact that the political system is in transition, perhaps it is understandable. However, the results do suggest that micro-finance projects contribute to female political empowerment and, thus, should be recognised as so doing. As such they become another instrument contributing to the change process.

Accordingly, the study concludes that micro finance projects do benefit Egyptian women psychologically and to a lesser extent socially, economically and politically, though perhaps the desired economic empowerment is not as effective as might be necessary to contribute significantly to the alleviation of poverty in Egypt. After decades of micro-finance support poverty remains prevalent in the country suggesting the need for a radical change in how micro-finance is delivered. On the basis of this research, certainly it should not be terminated but it does seem to need to be rethought, based on further, more in-depth analysis and research. 


\section{References}

- Agnes, Y (2012). "Engendering Microfinance Services: Beyond Access." Paper presented at the Women's Empowerment or Feminisation of Debt2 Workshop, London, March.

- $\quad$ Amolat, F. R. (2010) Client Impact Assessment: KMBI Prodgram Impact Assessment for Microfinance Implementation for Region 1.

- $\quad$ Anderson, L., Locker, L., Nugent, R., (2013), Microcredit, Social Capital, and Common Pool Resources, World Development, Vol.30, No.1, 95-105.

- $\quad$ Ashe, J., and Lisa P. (2010). Impact Evaluation of PACT's Women's EmpowermentProgram in Nepal: A Savings and Literacy Led Alternative to Financial InstitutionBuilding. Cambridge, Mass: Brandeis University.

- Barsoum, G., (2011). Who gets credit2 The Gendered Division of Microfinance Programs in Egypt, Canadian Journal of Development Studies.

- Bayulgen, O. Yunus, M and Grameen Bank (2012). What Political Science can contribute to and learn from the study of Microcredit, International Studies Review, Vol. 4, pp. 525-547.

- Chalfin, B. (2010). “Risky Business: Economic Uncertainty, Market Reforms and Female Livelihoods in Northeast Ghana." Development and Change. Vol, 2. No. 31. Pp. 987-1008.

- Deshpanda, R. (2012). Increasing Access and Benefits for Women: Practices and Innovations among Microfinance Institutions-Survey Results. New York: UNCDF.

- Drolet, J., (2010 a). Feminist Perspectives in Development: Implications for women and Microcredit. Vol 3, pp. 43-62.

- Drolet, J. , (2010 b). Women, Microcredit and Empowerment in Cairo, Egypt, International social work. Vol 5, pp. 23-35.

- $\quad$ Druschel, K. (2013). "State of the Microcredit Summit Campaign Report." Washington, D.C: Microcredit Summit Campaign Secretariat.

- Dunford, C. (2013). "Building Better Lives: Sustainable Integration of Microfinance with Education in Health, Family Planning and HIV/AIDS Prevention for the Poorest Entrepreneurs." Washington, D.C: Microcredit Summit Campaign.

- Engle, P. (2012). “Father's Money, Mother's Money, and Parental Commitment: Guatemala and Nicaragua." In Engendering Wealth and Well-Being: Empowerment for Global Change. Ed. RaeLesser Blumberg et al. Boulder, Colo: Westview Press.

- MkNelly, B. and M. McCord (2015). “Credit With Education Impact Review No. 1:Women's Empowerment." Freedom From Hunger. Vol. 3, pp 430-451

- Nader, Y., (2012). Microcredit and the socio-economic wellbeing of women and their families in Cairo. The Journal of Socio-economics 37 (2008) 644-656. no. 1. pp: 45-63.

- $\quad$ Oxaal, Z., Baden, S., (2013). Gender and Empowerment: definitions, approaches and implications for policy. Institute of Development Studies. University of Sussex, UK. Vol. 3, pp 532-556.

- Quisumbing, A., and Maluccio, J., (2014). Household Allocation and Gender Relations: New Em- 
pirical Evidence. Policy Research Report on Gender and Development Working Paper Series, No. 2. Washington, D.C: The World Bank Development Research Group/Poverty Reduction and Economic Management Network,

- $\quad$ Rahman, A. (2015). “Micro-credit Initiatives for Equitable and Sustainable Development: Who Pays2" World Development 27, no. 1. pp: 67-82.

- $\quad$ Razavi, S. (2014). "From Rags to Riches: Looking at Poverty from a Gender Perspective."IDS Bulletin 28, no. 3. pp: 49-62.

- $\quad$ Saith, R., and Harriss-White, B., (2013). "The Gender Sensitivity of Well-Being Indicators." Development and Change. Vol. 3. No. 30. pp: 465-97.

- $\quad$ Salib, S., (2014). FORA's Impact among Migrants: Primary Findings. Oak Brook, Ill: Opportunity International Network. Vol. 3, pp. 56-82.

- Sen, G. (2012). “Engendering Poverty Alleviation: Challenges and Opportunities."Development and Change. Vo. 2. No. 30. pp: 685-92.

- $\quad$ UNDP (2010) Human Development Report. New York: UNDP.

- $\quad$ UNDP (2013) National Impact Survey of Microfinance in Egypt. Egypt. UNDP.

- $\quad$ USAID (2013). Microenterprise Development in a Changing World: U.S. Agency for International Development Microenterprise Results Reporting for 2000. Arlington, Va: Weidemann Associates.

- Whitehead, A., and Lockwood, (2011). “Gendering Poverty: A Review of Six World Bank African Poverty Assessments." Development and Change. Vol. 2, pp. 525-55.

- Women's Entrepreneurship Development Trust Fund (WEDTF). Information on Microfinance and Empowerment of Women. Zanzibar, Tanzania: WEDTF.

- World Bank (2015).A Better Investment Climate for Everyone.World Development Report. Washington, DC: World Bank. 